WSRC-TR-94-0371, Rev. 4

\title{
Radioisotope Characterization of HB Line Low Activity Waste
}

by

S. J. Snyder

Westinghouse Savannah River Company

Savannah River Site

Aiken, South Carolina 29808

DOE Contract No. DE-AC09-89SR18035

This paper was prepared in connection with work done under the above contract number with the U. S. Department of Energy. By acceptance of this paper, the publisher and/or recipient acknowledges the $U$. S. Government's right to retain a nonexclusive, royalty-free license in and to any copyright covering this paper, along with the right to reproduce and to authorize others to reproduce all or part of the copyrighted paper. 


\section{DISCLAIMER}

This report was prepared as an account of work sponsored by an agency of the United States Government. Neither the United States Government nor any agency thereof, nor any of their employees, makes any warranty, express or implied, or assumes any legal liability or responsibility for the accuracy, completeness, or usefulness of any information, apparatus, product, or process disclosed, or represents that its use would not infringe privately owned rights. Reference herein to any specific commercial product, process, or service by trade name, trademark, manufacturer, or otherwise does not necessarily constitute or imply its endorsement, recommendation, or favoring by the United States Government or any agency thereof. The views and opinions of authors expressed herein do not necessarily state or reflect those of the United States Government or any agency thereof.

This report has been reproduced directly from the best available copy.

Available to DOE and DOE contractors from the Office of Scientific and Technical Information, P.O. Box 62, Oak Ridge, TN 37831; prices available from (615) 576-8401.

Available to the public from the National Technical Information Service, U.S. Department of Commerce, 5285 Port Royal Road, Springfield, VA 22161. 


\section{DISCLAIMER}

Portions of this document may be illegible in electronic image products. Images are produced from the best available original document. 


\section{ORIGINAL}

WSRC-TR-94-0371

Revision 4

\section{CHARACTERIZATION OF HB-LINE LOW-LEVEL WASTE}

June, 1998

Author:

Concurrence:

Reviewed by:

Approver:

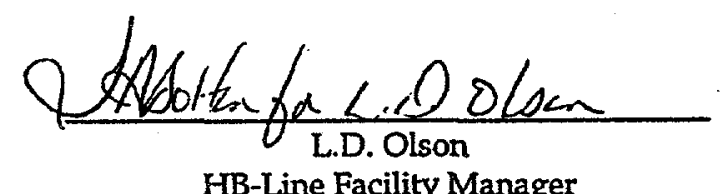

HB-Line Facility Manager

Nuclear Materials Stabilization \& Storage

\section{Tamara E. Baldwin}

HB-Line Systems Engineering

Nuclear Materials Stabilization \& Storage

C. J. Ward

Waste Engineer

Nuclear Materials Stabilization \& Storage

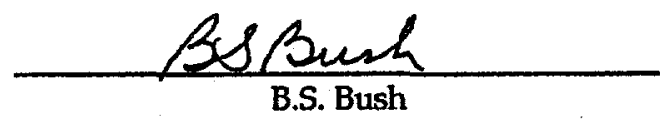

HB-Line Certification Official

Nuclear Materials Stabilization \& Storage

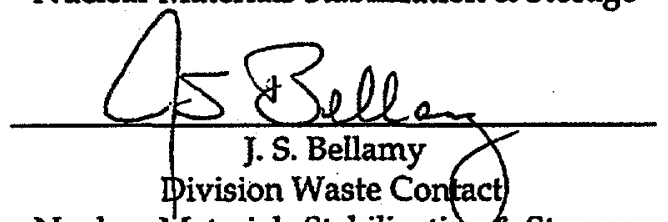

Nuclear Materials Stabilization? \& Storage

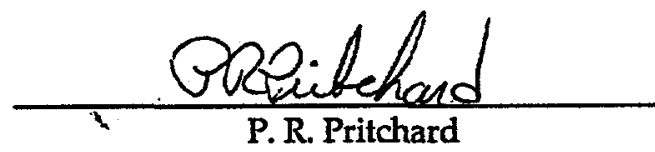

HB-Line System Engineering Manager Nuclear Materials Stabilization \& Storage

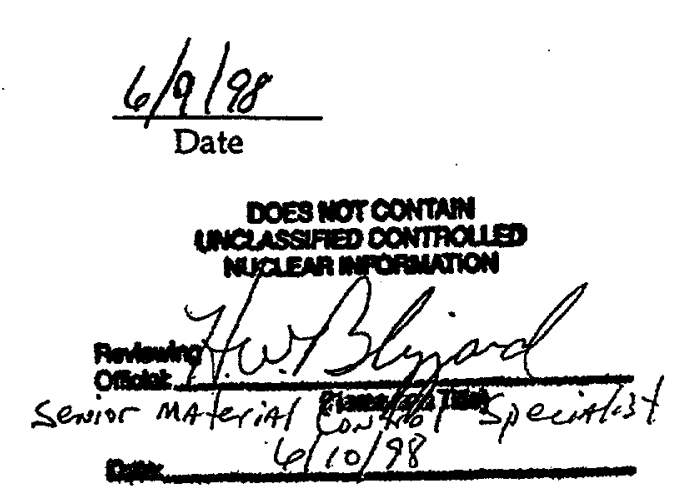


CONTENTS

\subsection{SUMMARY}

2.0 INTRODUCTION AND PROCESS DESCRIPTION

3.0 PHYSICAL, CHEMICAL AND HAZARDOUS CHARACTERIZATION

3.1 E-AREA VAULT

3.2 CONSOLIDATED INCINERATOR FACILITY

4.0 RADIONUCLIDE CHARACTERIZATION

4.1 WASTE STREAM DETERMINATION

4.2 RADIOISOTOPE DISTRIBUTION

4.3 CURIE DETERMINATION

4.4 COMPARISON WITH TREATMENT, STORAGE, AND DISPOSAL FACILITY GUIDELINES

5.0 NUCLEAR SAFETY GHARACTERIZATION

$5.1 \quad$ EAV

5.2 CIF

6.0 WASTE PACKAGING, LABELING, MARKING, TRANSPORTATION, AND ADMINISTRATION CRITERIA

7.0 PLAN VALIDATION

8.0 REFERENCES APPENDIX A APPENDIX B APPENDIX $C$ 


\section{CHARACTERIZATION OF HB-LINE LOW-LEVEL WASTE}

1.0

\section{SUMMARX}

The purpose of this document is to provide a physical, chemical, hazardous and radiological characterization of Low-Level Waste (LLW) generated in HB-Line as required by the is Manual, Savannah River Site Waste Acceptance Criteria Manual (Reference 2). For the waste to be categorized as $L L W$, it must contain no more than 100 nanoCuries (nCi) of transuranic (TRU) isotopes per gram of waste.

\subsection{INTRODUCTION AND PROCESS DESCRIPTION}

HB-Line consists of three distinct facilities; the Scrap Recovery Facility, the Neptunium Oxide Facility and the Plutonium Oxide Facility. These operations are located on the fifth and sixth levels of Building 221-H. A brief description of each facility is provided below. The LLW generated from these processes is predominately job control waste that has only minimal amounts of radioactive contamination. The LLW contamination results from.contact with incidental contamination found on the walls and floors in operating and maintenance areas, and exterior surfaces of process cabinets and gloveboxes. Measurable contamination on HBLine LLW occurs infrequently, and spots of contamination, when found, are typically of low concentrations.

\section{Scrap Recovery Facility}

Scrap Recovery Facility operations include opening, repackaging, screening, size reducing and dissolving scrap. The Scrap Recovery Facility (Phase I) current mission is to dissolve Pu-239 sweepings from FB-Line. A general process flowchart for the Scrap Recovery facility is provided in Figure 1.

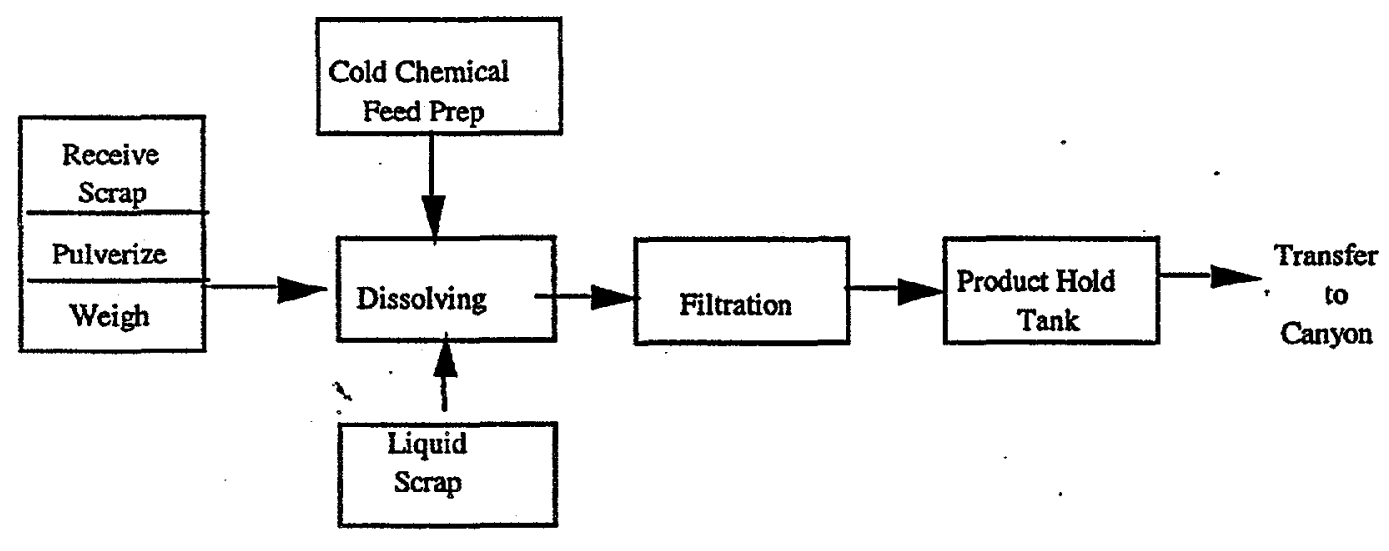

Figure 1. Scrap Recovery Facility Flowchart

Chemicals used in Phase I include nitric acid, potassium fluoride and aluminum nitrate.

Nitric acid may cause severe burns. The $64 \%$ nitric acid is pumped from $211-\mathrm{H}$ to CFP-1, and from there is direct piped to the Phase I process. The $64 \%$ nitric acid is also diluted in CFP-1.

Potassium fluoride is an irritant. The potassium fluoride used in the Phase I process is stored and prepared in CFP-2. 
Aluminum nitrate is a mild irritant. This chemical is also a strong oxidizing agent and is stored separately from flammable and combustible materials. The aluminum nitrate solution used in the Phase I process is stored and prepared in CFP-1.

The HB-Line Facility also contains a Waste Handling Line that prepares contaminated items for TRU Waste disposal and also contains an Analytical Laboratory for analyzing samples.

For more information on the process description including, principle product, feed materials and process materials, refer to the HB-Line Basis for Interim Operation, WSRC-RP-96-553.

\section{Plutonium Oxide Facility}

This facility is not being utilized during the Pu-239 campaign, but surveillance and maintenance activities continue to generate low level waste contaminated with the Pu-242/ Pu-238 distribution.

The purpose of the HB-Line Plutonium Oxide (Phase $\mathrm{II}$ ) process is to produce plutonium oxide powder (PuO2). The original mission for the plutonium oxide facility was to produce Pu-238 oxide for Los Alamos National Laboratory (LANL). The recent mission for the Plutonium Oxide Facility was to produce $\mathrm{Pu}-242$ oxide for the stabilization effort of the 94-1 material.

Figure 2 is a simplified flow diagram of the HB-Line Phase III process. In the case of Pu-238, Pu-238 nitrate solutions are received from the H-Canyon Frames Process. The nitric acid molarity $(\mathrm{M})$ is adjusted and the valence of the plutonium is reduced using ascorbic acid and hydrazine. Oxalic acid is added to form plutonium oxalate which precipitates out of solution. The plutonium oxalate is calcined in a furnace to produce the $\mathrm{Pu}-238$ oxide powder. The $\mathrm{Pu}$ 238 oxide powder is then packaged and shipped to LANL. Pu-242 is precipitated in the same manner; however, it is not valence adjusted with ascorbic acid and hydrazine.

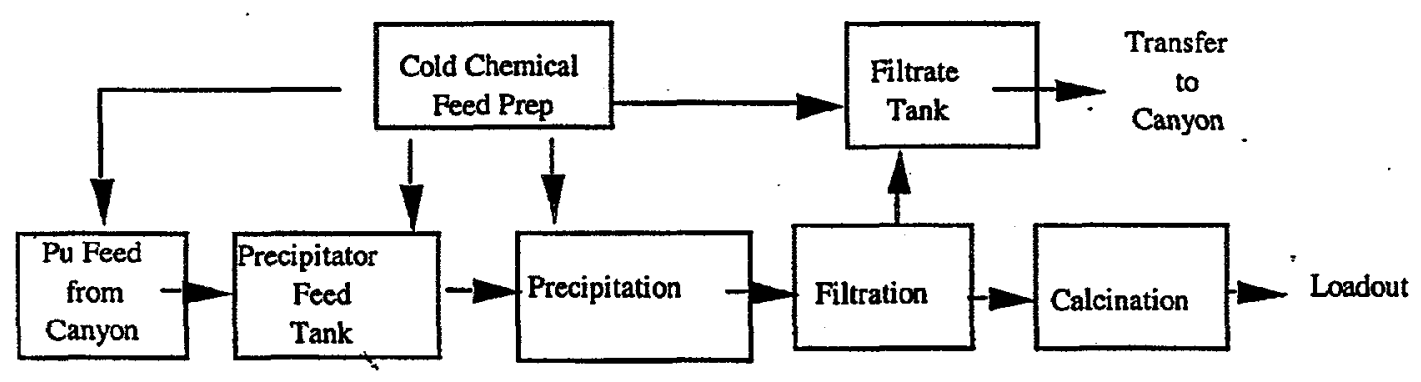

Figure 2. Plutonium Oxide Facility

The chemicals used in Phase III include $64 \%$ nitric acid, ascorbic acid, oxalic acid, potassium permanganate, and hydrazine mononitrate. Pu-242 did not use ascorbic acid or hydrazine mononitrate, but HB-Line continues to have these chemicals. All chemicals are prepared in the Phase III CFP-2 room located on the sixth level. All acid spills are neutralized prior to being disposed.

Ascorbic acid is harmless in the concentrations used in the process.

Nitric acid may cause severe burns. The $64 \%$ nitric acid is pumped from $211-\mathrm{H}$ to $\mathrm{CFP}-2$, and from there is direct piped to the Phase III process. The $64 \%$ nitric acid is also diluted in CFP-2. 
Solid oxalic acid will cause severe burns. The oxalic acid solution is less dangerous since it is relatively dilute. The oxalic acid solution used in the Phase III process is prepared from solid oxalic acid crystals in CFP-2. Potassium permanganate may cause burns when in high concentrations. Potassium permanganate solution used in the Phase III process is prepared from solid potassium permanganate crystals in CFP-2.

Hydrazine is a suspected carcinogen. Solid hydrazine will burn rapidly in air and vapor may explode in fire. Solid hydrazine is never brought into the HB-Line Facility. It is delivered as $30 \%$ hydrazine mononitrate solution in drums. Hydrazine mononitrate is less dangerous than solid hydrazine but still a significant concern. Suspected hydrazine mononitrate spills are tested and cleaned up by Industrial Hygiene.

For more information on the process description including, principle product, feed materials and process materials, refer to DPSTSA-200-10-2 SUP 2C, Section 3.3.

All material handling is performed in gloveboxes to help prevent the spread of contamination. All waste generated from the gloveboxes is treated as TRU waste:and, as such, is outside the scope of this plan.

\section{Physical, Chemical, and Hazardous Characterization.}

\subsection{E-Area Vault (EAV)}

\subsubsection{Physical Characteristics of the Waste}

The materials in the waste stream going to the E-Area vaults will be material prohibited from the Consolidated Incinerator Facility (CIF), predominantly: supplied air hoses, fresh air hoods, huts, non-functioning valves and pumps, sections of carbon steel and stainless steel pipe, scaffolding materials, and aerosol cans. Small pieces of structural material (concrete) will also be included in this waste stream.

\subsubsection{Transuranic Waste}

Waste packages containing TRU isotopes exceed $100 \mathrm{nCi} / \mathrm{g}$ of waste àre classified as . TRU waste. Such waste must be handled differently from low-level waste. To ensure that no HB-Line waste exceeds the package limits for any of the radioisotopes, the distributions for process material have been composited to generate a curie calculation algorithm.

A waste package from HB-Line will exceed $100 \mathrm{nCi} / \mathrm{g}$ when it is generated in a room with RCHP posted removable alpha contamination greater than $7.43 \times 10^{7} \mathrm{dpm} / 100 \mathrm{~cm}^{2}$ (non-hut waste) and $1.32 \times 10^{5} \mathrm{dpm} / 100 \mathrm{~cm}^{2}$ (hut-waste). These limits are calculated in Appendix B.

\subsubsection{Hazardous Waste, Toxic Gases, Vapors, and Fumes}

There are two means by which hazardous material could enter the HB-Line LLW streams. The first is by contamination with process material. The second is by the use of a product in HB-Line which would be considered a hazardous waste when disposed.

The following is a list of all hazardous constituents used in the HB-Line Process Line: Cadmium (Cd), Lead (Pb), and Chromium (Cr). 
The process knowledge dictates that these hazardous constituents will not be present above the RCRA regulatory units from the low level contamination of process material. A detailed analysis is described in NMP-EHA-93-0754. Based on the allowable concentrations of plutonium in the LLW stream, the maximum expected concentration of the hazardous component was determined to be far below the RCRA regulatory limits; therefore, there is no concern of hazardous waste inclusion in the Low Level Waste Streams as a result of contamination from process material.

All chemicals used in HB-Line are tracked by the HB-Line Chemical Coordinator. The Chemical Coordinator also maintains sets of Material Safety Data Sheets (MSDS) for these chemicals. Chemicals which may create RCRA hazardous wastes must be reviewed by the Chemical Coordinator and are approved for use only if a Nonhazardous substitute cannot be used. The Blue Dot Program is implemented in HBLine to identify chemical which may contain hazardous elements. The Blue Dots are placed on these chemicals to identify the container and allow the waste handler to recognize that the waste generated may be considered a RCRA (Mixed) Waste. All Blue Dot containers can be disposed of as regular RAD waste in HB-Line only if the container is empty. Although Low-Level Mixed Waste is not expected to be generated in HB-Line, mixed waste,staging areas are located within the facility for hazardous waste segregation and temporary storage.

Personnel who enter HB-Line are trained to identify the waste generated (including any possible hazardous or mixed waste) and dispose of the waste in the proper waste receptacle.

\subsubsection{Other}

HB-Line does not process or use explosives, pyrophoric material, etiologic agents, chelating agents, dioxins, or furans nor does HB-Line generate greater than 10CGF71 Class $\mathrm{C}$ wastes.

Free liquids are stabilized using approved absorbents per NOP 221-HB-4700. Pressurized containers are prohibited from the LLW streanis.

HB-Line does not process tritium gas. Exit signs that contain tritium are prohibited from disposal in LLW streams. As a result, there will be no detectable offgassing tritium from $\mathrm{HB}-\mathrm{Line}$ waste containers.

\subsection{Consolidated Incineration Facility (CIF)}

\subsubsection{Physical Characteristics of the Waste}

LLW from HB-Line is predominantly job control waste, as described in Reference 1, that has only minimal amounts of radioactive contamination. The distribution is based on the GCO's process knowledge for LLW routinely handled in the facility.

\subsubsection{Transuranic Waste}

Waste packages containing TRU isotopes that exceed $100 \mathrm{nCi} / \mathrm{g}$ of waste are classified as TRU waste. Such waste must be handled differentiy from low-level waste. Using the present computation algorithm, a waste package from HB-Line will exceed $100 \mathrm{nCi} / \mathrm{g}$ when it is generated in a room with RCHP posted removable alpha contamination 
greater than $7.43 \times 10^{7} \mathrm{dpm} / 100 \mathrm{~cm}^{2}$ (non-hut waste) and $1.32 \times 10^{5} \mathrm{dpm} / 100 \mathrm{~cm}^{2}$ (hutwaste). These limits are calculated in Appendix B.

\subsubsection{Sodium}

Three chemicals used in HB-Line Facilities process contain sodium. These chemicals are sodium hydroxide, sodium nitrite, and sodium carbonate (soda ash). When sodium hydroxide is present in the radiologically controlled areas, it is in liquid form. Sodium nitrate may be in the solid or liquid form. Sodium carbonate is in the solid form.

Solutions describe above are contained in piping and transferred into the process and are not routine part of the LLW stream. Spills of these chemicals would be contained in sumps and processed in the liquid waste processing systems. Waste containing greater than trace amounts of these solutions will be directed into EAV waste stream.

Soda ash is used to neutralize acid spills within the facility. Cleanup materials are disposed of as directed by the Generator Certification Official (GCO). Waste containing greater than trace amounts of soda ash will be directed into the EAV waste stream.

Typical site job control waste was analyzed by Solid Waste Division Generator Services (Reference 1) to determine the contents of the raw materials that consititute the bulk of LLW streamis. This analysis determined that non-PVC containing waste (which is representative of the HB-Line LLW job control waste streams) contains $448 \mathrm{ppm}$ sodium (Table 7, Reference I) which is well below the 10 weight percent limit in the WAC.

\subsubsection{Organic Fluoride}

Organic Fluorides are not used in any HB-Line processes. The study performed and documented in Table 7 of Reference 1 found that the total fluoride content of the raw materials in non-PVC containing waste is $168 \mathrm{ppm}$ which is well below the 10 weight percent in the WAC (Reference 2).

\subsubsection{Standard 8 Air Toxic Chemicals}

HB-Line does not use any of the following chemicals in processing nor are they contained in the raw material streams that make up job control waste. The chemicals are: Hezamethylene-1, 6-diisocyanate, p-Aminodiphenyl, kepone, a-Naphtylamine, bNaphtylamine, nitrogen mustard, nitrosodimethylamine, or p-Nitrosophenol.

\subsubsection{Hazardous Metals}

\subsubsection{Hazardous Metals From Non-Process Chemical Usage}

Hazardous metals have the potential for getting into the LLW stream through person inappropriately discarding a chemical product (e.g., a non-empty can of hazardous paint). This is controlled administratively through procedures, training and the chemical control program.

\subsubsection{Hazardous Metals in the Job Control Waste}

Hazardous metals are also present in trace amounts in the job control waste stream raw materials. A characterization of the raw materials in the job control waste was performed by Solid Waste Division Generator Services (Reference 1). 
WSRC-TR-94-0371 •

Revision 4

The hazardous metals content of HB-Line job control waste is shown in the nonPVC job control waste of Table 7, Reference 1.

\subsubsection{Hazardous Metals in the Process}

An analysis was performed to determine the maximum attainable quantities of the hazardous components in HB-Line LLW (see appendix C). A review of the South Carolina Hazardous Waste Management Regulations and the Low Level Waste Classification document (NMP-EHA-93-0754) was performed to compare the process chemicals to the hazardous waste list. It was determined that lead (Pb), cadmium (Cd) and chromium are the only hazardous metals that should be found in HBL LLW. To determine the amount of hazardous metals in waste the analysis assumes that the ratio of hazardous material to plutonium $(\mathrm{Pu})$ in the LLW is equal to the ratio of hazardous material to $P u$ in the process streams. A worst case was analyzed (i.e, waste at the TRU limit). These values, in addition to the contribution added by the job control waste will be reported on the characterization form.

\subsubsection{Heat Content}

A characterization of the raw materials in the job control waste was performed by Solid Waste Division Generator Services (Reference 1). The heat content of HB-Line job control waste is best represented by the non-PVC job control waste, shown in Table 7 of Reference 1 which gives a heat content of $12,700 \mathrm{BTU} / \mathrm{lb}$.

\subsubsection{Percent Ash}

A characterization of the raw materials in the job control waste was performed by Solid Waste Division Generator Services (Reference 1). The percent ash of burned HB-Line job control waste is best represented by the non-PVC job control waste, shown in Table 7 of Reference 1 which gives an ash content of $3.47 \%$.

\subsubsection{Halogen Content}

Per Reference 1, the halogen content (chlorine, fluorine, bromine) of HB-Line waste is approximately $15,486.7 \mathrm{mg} / \mathrm{kg}$. With an average bag weighing $35 \mathrm{lbs}$ (i.e., $16 \mathrm{~kg}$ ), the average weight percent of halogens per bag of CIF waste is $1.5 \%$. The number is derived by using the following assumptions:

HB-Line job control waste has the following amount of halogens:

\begin{tabular}{ll} 
Chlorine & $15,300.0 \mathrm{mg} / \mathrm{kg}$ \\
Fluorine & $168.0 \mathrm{mg} / \mathrm{kg}$ \\
Bromine & $18.7 \mathrm{mg} / \mathrm{kg}$ \\
\hline Total & $15,486.7 \mathrm{mg} / \mathrm{kg}$
\end{tabular}

The average bag of waste weighs approximately 35 pounds (i.e.,15.88kg). The average amount of halogens per bag of waste then equates to $15,487 \mathrm{mg} / \mathrm{kg} \times 15.88 \mathrm{~kg}=245,933$ $\mathrm{mg}$ of halogens. The average weight percent of halogens in a HB-Line CIF bag of waste: $.245 \mathrm{~kg} / 15.88 \mathrm{~kg} \times 100=1.5 \%$ 


\subsection{Other}

HB-Line does not process or use explosives, pyrophoric materials, etiologic agents, chelating agents, dioxins, or furans, nor does HB-Line generate greater than 10 CFR71 Class $\mathrm{C}$ waste.

Free liquids are stabilized using approved absorbents and pressurized containers are prohibited from the LLW streams. Metal containers and pressure treated wood are prohibited from the CIF waste stream.

HB-Line does not process tritium gas. Exit signs that contain tritium are prohibited from disposal in LLW streams. As a result, there will be no detectable offgassing tritium from $\mathrm{HB}-\mathrm{Line}$ waste containers

\subsection{RADIONUCLIDE CHARACTERIZATION}

\subsection{Waste Stream Determination}

Radioactive waste generated in HB-Line is segregated into the following categories:

- Low-Level Radioactive Solid Waste

- LLW Oil

- Low-Level Mixed Waste (not currently generated in HB-Line)

- TRU Waste

- TRU Mixed Waste

To provide a physical barrier against personnel contamination, all processing in HB-Line is performed in process cabinets and gloveboxes. The process cabinets and glove box sections contain the process vessels, valves, product filters, as well as most of the piping and other miscellaneous equipment. All waste (including maintenance waste) from the process cabinets and gloveboxes shall be collected, packaged and handled as TRU Waste in acccordance with all applicable procedures. Therefore, waste streams resulting from process cabinet and glovebox waste will not be included in the LLW classification.

A simplified diagram of the HB-Line process is shown in Figure 3. Both $\mathrm{Pu}-238$ and $\mathrm{Pu}-239$ waste streams can be adequately represented by the radioisotope distribution of the feed stream from the canyon frames process $\left(\mathrm{D} 1^{+}\right)$. An adjustment is made for the growth of U-233 and U234 in scrap material (Pu-238 only) as a result of the decay of Np-237 and Pu-238, respectively. Details of this adjustment is provided in the Derivation of Algorithm section.

Using the distribution for $\mathrm{Pu}-238\left(\mathrm{D} 1^{*}\right)$ is possible because of the following conditions:

(1) the $\mathrm{Pu}$ in the process stream is passed through HB-Line with very little loss,

(2) most contaminants in the HB-Line Pu feed (including Pu-238 scrap) are at extremely low concentrations,

(3) some waste streams are inextricably mixed with others, and

(4) the plutonium distribution of the Pu-238 scrap is essentially the same as the plutonium distribution in a Mark 53A. 
Because the radioisotope distribution of main process material undergoes little change, the radioisotope distribution of the HB-Line Pu feed from the canyon frames will envelop the actual radioisotope distribution at each stage of the main line process. Also, the relative concentrations of the $\alpha$-emitting isotopes $\mathrm{Pu}$ and $\mathrm{Am}$, on which the radioisotope quantification algorithm is based, are essentially unchanged. Therefore, the Pu-238 distributions D2 and D3 are encompassed by the Pu-238 distribution $\mathrm{D} 1 *$.

The Pu-239 campaign will only involve the Scrap Recovery Facility. The distribution of the Pu239. waste stream will be the FB-Line distribution. All Pu-239 material being dissolved is from FB-Line. While FB-Line is using their feed stream as the isotopic distribution, it is still valid for $\mathrm{HB}$-Line because the isotopes that are affected by FB-Line processing are $95 \mathrm{Zr}, 95 \mathrm{Nb}, 103 \mathrm{Ru}$, and 106Ru. These isotopes are not required to be declared for EAV disposal and are not in sufficient quantity that the FB-Line processing changes the overall distribution.

\section{HB-Line Simplified Process Flow Diagram}

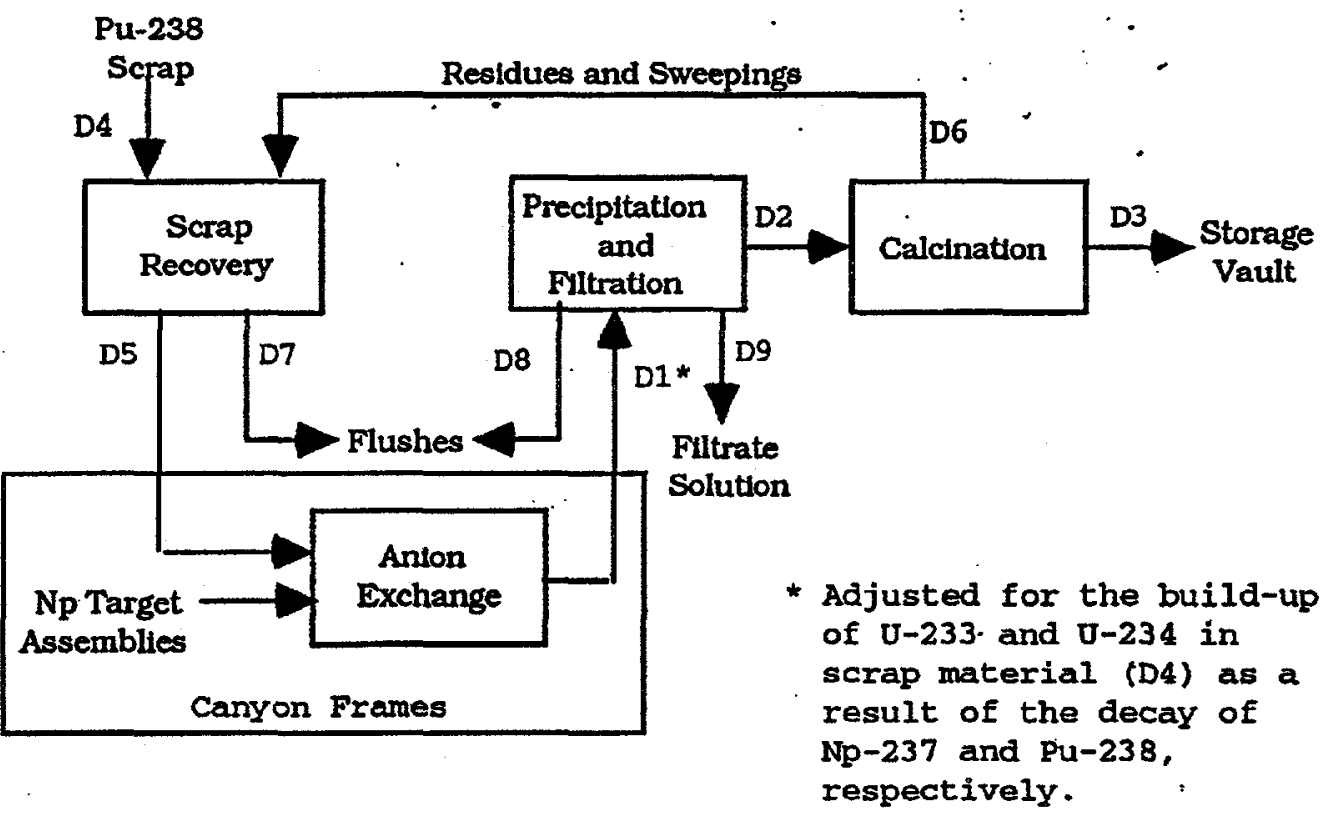

Figure 3. Simplified Process Flow Diagram of HB-Line. This diagram shows the process points that can concentrate or separate elements, and hence possibly change the radioisotope distribution. Possible distinct distributions are indicated by the labels $\mathrm{D1}{ }^{*}$ through $\mathrm{D} 9$. 
Radioisotope characterization of low-activity waste involves two distinct components: determining the radioisotope distribution in the waste and determining the radioisotope content in a waste package. The radioisotope distribution and the waste matrix (non-radioactive waste material) define a waste stream. In general the properties of a waste stream are determined for all or part of a facility initially and at intervals throughout its lifetime, and the waste stream characteristics in effect at a given time are assumed for all waste items leaving the facility (or appropriate part of the facility). The radioisotope contents, on the other hand, are determined for each package of waste using such measured parameters as external gamma radiation dose, nondestructive assay, room or area contamination levels, and package weights. The two characterization components - distribution and content - are discussed in more detail in the following sections.

\subsubsection{Pu-238 Radioisotopic Distribution}

Sample analysis data are available for the $\mathrm{Pu}$ isotopes, but not most of the other radioisotopes that the 1S Manual requires to be reported. This situation is a result of the fact that the frames process is so effective at removing most isotopes having a strong gamma signature, like $60 \mathrm{Co}$ and ${ }^{137} \mathrm{Cs}$, and the fact that analyses for many $\beta$-emitting isotopes have never been performed. Only analyses that were important to the product specifications of the $\mathrm{Pu}-238$ Oxide and to radiation safety have been performed routinely.

Because of the lack of adequate data for the concentrations of other contaminating radioisotopes, another approach was required for the complete characterization of the HB-Line Feed. The approach developed was to use, as a starting point, the isotope concentrations given for the Mark 53A target assemblies in Reference 13. These concentrations were calculated in two steps. First, a GLASS computer calculation provides neutron fluxes and spectrum-averaged cross sections at various times during irradiation. Second, the fluxes and cross sections from GLASS are used by the FPCALCG module of the SHIELD system to compute the isotopic inventory (reference 1). The first step is necessary since actinide isotopic inventories are sensitive to detailed neutron flux spectrum effects. This calculation computes most of the radionuclides within each assembly at the end of irradiation. The major exceptions which concern characterization are $\mathrm{H}-3$ and $\mathrm{Co}-60$.

The irradiated, decayed target content was input for metal dissolution (frames feed). This provided reference data for most of the required isotopes identified as isotopes of concern in the SRS Waste Acceptance Criteria (WAC, Reference 2). Upper limits on the concentrations of other activation products were inferred from process data or chemical properties. After dissolution the feed material in the canyon frames is processed through anion exchange columns on its way to HB-Line. The reduction in a contaminating element relative to Pu across the columns is called the decontamination factor (DF). DFs for elements (radioisotopes) required to be quantified by the WAC were provided from Reference 14. The application of these DFs to the irradiated Mark 53A radioisotope distribution provides an estimate of the radioisotope distribution of HB-Line feed (7.3-1). The results are summarized in Table 1. All calculations for synthesis of the distribution are given in WSRC-TR-94-0371, Rev. 3. 
Table 1 defines the radioisotope distribution for HB-Line Pu-238 LLW. Distribute the calculated total activity value $T$ among the various reportable radioisotopes according to the relative activity factors (Rel Activity) in the table. The activity of each isotope in the waste item is obtained by multiplying the total activity $\mathrm{T}$ by the corresponding factor in the table.

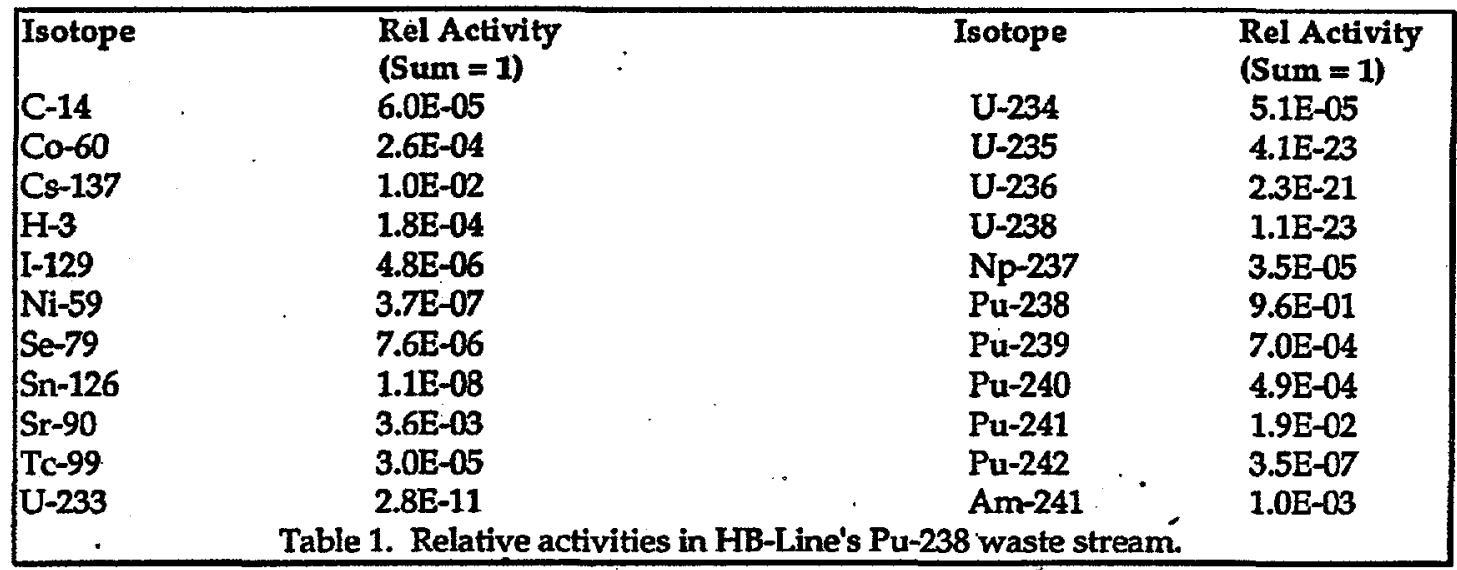

\subsubsection{Pu-239 Radioisotopic Distribution}

The distribution for the Pu-239 material was decayed from FB-Line' validated distribution. Table 2 defines the radioisotope distribution for HB-Line Pu-239 LLW. Distribute the calculated total activity value $T$ among the various reportable radioisotopes according to the relative activity factors (Rel Activity) in the table. The activity of each isotope in the waste item is obtained by multiplying the total activity $T$ by the corresponding factor in the table.

\begin{tabular}{|c|c|c|c|c|c|}
\hline Isotope & & $\begin{array}{l}\text { Rel Activity } \\
\text { (Sum = 1) }\end{array}$ & & Isotope & $\begin{array}{l}\text { Rel Activity } \\
\text { (Sum = 1) }\end{array}$ \\
\hline C-14 & & $7.2 \mathrm{E}-08$ & & $\mathrm{U}-234$ & 3.7E-14 \\
\hline Co-60 & & $0.0 \mathrm{E}-00$ & & U-235 & $5.8 \mathrm{E}-13$ \\
\hline Cs-137 & & $2.0 \mathrm{E}-06$ & & U-236 & $5.8 \mathrm{E}-13$ \\
\hline $\mathrm{H}-3$ & & 3.1E-05 & & U-238 & $5.4 \mathrm{E}-11$ \\
\hline $\mathrm{I}-129$ & & $5.9 \mathrm{E}-13$ & & $\mathrm{~Np}-237$ & $1.6 \mathrm{E}-09$ \\
\hline $\mathrm{Ni}-59$ & & 1.7E-05 & & $\mathrm{Pu}-238$ & $2.7 \mathrm{E}-03$ \\
\hline $\mathrm{Se}-79$ & 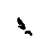 & $7.2 \mathrm{E}-12$ & - & $\mathrm{Pu}-239$ & 9.1E-02 \\
\hline Sn-126 & & $1.2 \mathrm{E}-12$ & & $\mathrm{Pu}-240$ & $2.1 \mathrm{E}-02$ \\
\hline $5 r-90$ & & $1.5 \mathrm{E}-06$ & & Pu-241 & 8.7E-01 \\
\hline Tc-99 & & $2.7 \mathrm{E}-10$ & & $\mathrm{Pu}-242$ & $2.0 \mathrm{E}-06$ \\
\hline U-233 & & $7.1 \mathrm{E}-14$ & & Am-241 & $1.8 \mathrm{E}-02$ \\
\hline
\end{tabular}

Table 2 Relative activities in HB-Line's Pu-239 waste stream. 


\subsubsection{Pu-242 Radioisotopic Distribution}

Table 3 below defines the radioisotope distribution for HB-Line Pu-242 LLW. Distribute the calculated total activity value $T$ among the various reportable radioisotopes according to the relative activity factors (Rel Activity) in the table. The activity of each isotope in the waste item is obtained by multiplying the total activity $\mathrm{T}$ by the corresponding factor in the table.

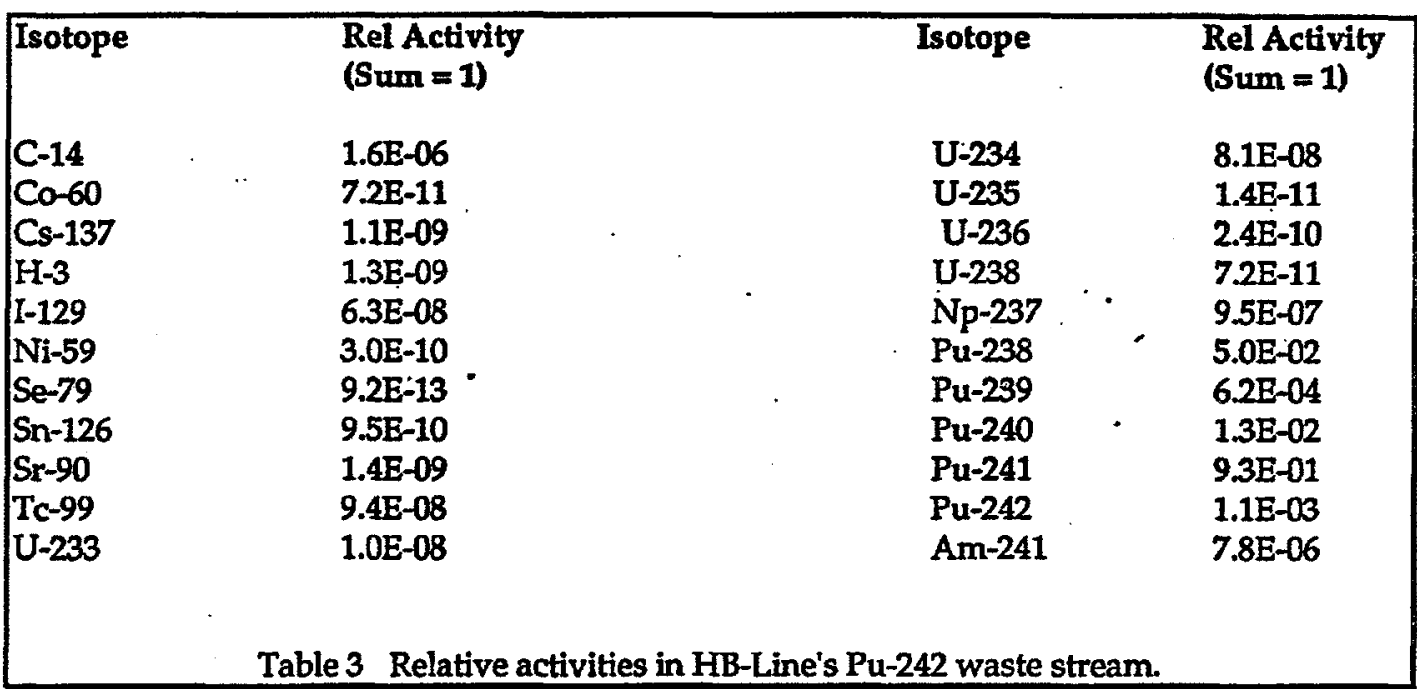

\subsubsection{HB-Line Composite Radioisotopic Distribution}

The total activity calculated from the appropriate above equation is attributed to each of the reportable isotopes by multiplying the total activity by the corresponding factor in the listed below:

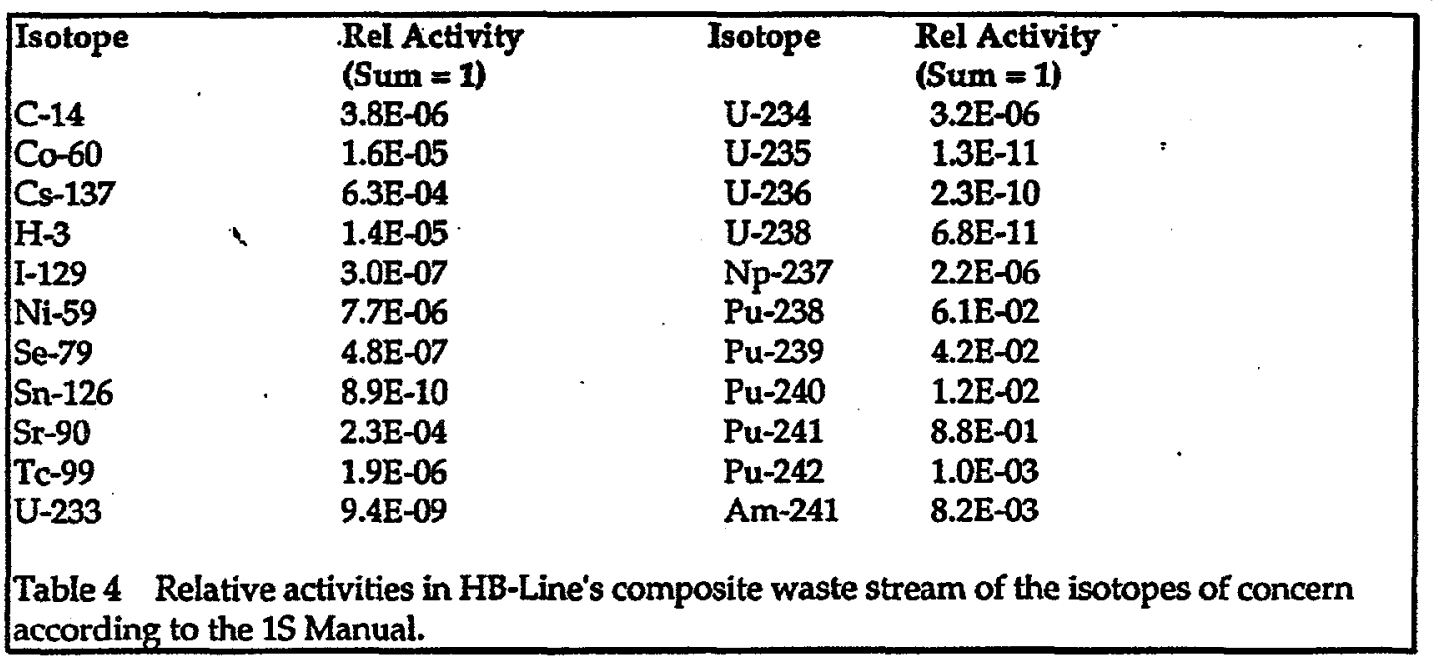


As HB-Line continues to change missions, the facility low level waste distribution continues to change. To ensure that no HB-Line waste exceeds the package limits for any of the radioisotopes, the distributions for the process material have been composited and a new curie calculation algorithm generated. HB-Line plans to use this composite for all low level waste generated during $\mathrm{Pu}-238, \mathrm{Pu}-242$, and $\mathrm{Pu}-239$ processing and all related activities.

Appendix A provide the calculations for the final composite distribution, the development of the smear-to-curie conversion algorithms, the associated algorithm limits, and the reportability requirements.

\subsubsection{Curie Determination for Non-Hut Waste}

The reportable Total Activity, [T] of an HB-Line non-hut LLW package is calculated from the equation:

$$
\pi\left[n C_{i}\right]=4.89 \times 10^{-3} \times \mathrm{A} \times \mathrm{W} \text { : }
$$

$\mathrm{T}=$. Total activity of waste package in nanoCuries (nCi) based on RCHP alpha smear counts, process knowledge, and study results,

$A=$ The greater of 1) 20000 or

2) the maximum alpha activity in $\mathrm{dpm} / 100 \mathrm{~cm}^{2}$ of removable contamination (RCHP posted room alpha activity at the time the waste is removed), and $W=\quad$ Net weight of the waste package in pounds.

Each room in the HB-Line radiological controlled area is posted with the highest count rate of removable alpha contamination found in that room during routine Radiological Control and Health Physics (RCHP) surveys. The RCHP-posted activity will be used as the maximum smearable alpha activity $(A)$ in the room, except in rooms with high contamination potential. In these rooms, the smearable alpha activity is assumed to be $200,000 \mathrm{dpm} / 100 \mathrm{~cm}$, the procedural limit HB-Line uses to distinguish between Low-Level and TRU waste. The waste is tagged with the room posting for internal HB-Line handling. The conservative value of 200,000 $\mathrm{dpm} / 100 \mathrm{~cm}^{2}$ is used for the reportable activity because facilities other than HB-Line handle HB-Line's low level waste based on the manifested value, rather than the potential contamination in the bag.

\subsubsection{Curie Determination for Hut Waste}

Hut waste is a separate case. Hut contamination is not inferred from the posted room alpha activity. Hut contamination is measured directly. Therefore, the characterization factor used for non-hut waste does not apply. Hut contamination is checked during hut cleanup by using an RCHP alpha survey meter, not by smears. Smears detect only removable contamination, and the hut must be checked for all remaining contamination, both removable and fixed. 
The reportable Total Activity, [T], of an HB-Line hut low level waste package is calculated from the equation

$$
\mathrm{T}[\mathrm{nCi}]=2.76 \times \mathrm{C} \times \mathrm{W}
$$

$T=$ Total activity of hut waste package in nanoCuries (nCi) based on alpha survey data, process knowledge, tests, and assumptions,

$\mathrm{C}=$. The maximum alpha activity in $\mathrm{dpm} / 100 \mathrm{~cm}^{2}$ of contamination on a hut as measured by RCHP using an alpha survey meter directly (not smears), and,

$W=$ Net weight of the hut waste package in pounds.

\subsection{Comparison with Treatment, Storage, and Disposal Facility Guidelines}

\subsubsection{Comparison with EAV Package Limits}

WAC 3.17 provides the guidelines for an acceptable package for EAV. Individual radionuclides guidelines are given as well as the $100 \mathrm{nCi} / \mathrm{g}$ TRU limit. Although a specific guideline is given for each radionuclide, the limit is the "sum-of-the-fraction" of activity of these radionuclides or the TRU limit, (whichever is lower). Appendix B compares these guidelines/limits to the relative activities and determines a contamination level at which a package would reach the "sum of the fraction" or TRU limit. The table below contains the limiting conditions. The limiting case will be placed in the facility procedure so that packages can be screened in the field to ensure that a limit will not be exceeded.

\begin{tabular}{|c|c|c|}
\hline & Non-Hut & Hut \\
\hline $\begin{array}{l}\text { Contamination level at which } \\
\text { EAV sum-of-fraction limit is reached }\end{array}$ & $4.50 \times 10^{t}$ & $7.97 \times 10^{5}$ \\
\hline $\begin{array}{l}\text { Contamination level at which } \\
\text { TRU limit is reached } \\
\text { *limiting case is in bold }\end{array}$ & $7.43 \times 10^{7}$ & $1.32 \times 10^{5}$ \\
\hline
\end{tabular}

\subsubsection{Comparison with CIF Package Limits}

WAC 3.17 provides the guidelines for an acceptable package for CIF. Alpha, tritium, TRU, total concentration and external package dose limits are given. Appendix B compares these guidelines/limits to the relative activities and determines a contamination level at which a package could reach the CIF limit. The results are shown in the table below. The limiting case will be placed in the facility procedure so that packages can be screened in the field to ensure that a limit will not be exceeded.

$\begin{array}{llll} & \text { H-3 } & \text { Alpha } & \text { Total Nuclides } \\ \text { HUT } & 6.63 \times 10^{34} & 7.47 \times 10^{7} & 2.10 \times 10^{10} \\ \text { NON-HUT } & 1.17 \times 10^{12} & 1.32 \times 10^{3} & 3.72 \times 10^{7}\end{array}$

"The limiting case is in bold 


\subsection{EAV}

The fissile material criterion limit for EAV is 50 grams of enriched U-235 fissile gram equivalent (FGE U-235) per container. The maximum grams per container for HB-Line waste is several orders magnitude below the 50 gram limit (see Appendix B). Actual values will be calculated by the Waste Information Tracking System (WITS).

5.2 CIF

The nuclear safety limit for CIF inventory is 624 FGE U-235. A generator specific FGE package limit has not been established. However, maximum and average FGE grams that would be shipped to CIF per package are shown in Appendix B. These values can be used by CIF burn planning personnel to ensure that HB-Line waste will not impact their operation and assist them in determining an outage schedule. Actual values will be calculated by WITS.

6.0 WASTE PACKAGING, LABELING, MARKING, TRANSPORTATION, ADMINSTRATION CRITERIA

Implementation of all packaging, labeling, marking, transportation, and administration criteria described in the WAC is addressed in the HB-Line Low Level and Mixed Radioactive Certification Plan and in NOP 221-HB-4700.

\subsection{PLAN VALIDATION}

Validation of the radioisotope distribution derived for HB-Line Pu-238 waste has been accomplished by analysis of smears from several HB-Line process areas for the isotopes specified in Reference 2. Reference 3 is the Sampling Plan for analysis of HB-Line process smears. The sample analysis results were compared with the calculated process analysis distribution. The finalized distribution is presented in Table 1. Periodic validation of the radionuclide content and distribution will occur every two years unless the waste stream meets the exceptions specified in WSRC 1S Manual, WAC 2.02. 
WSRC-TR-94-0371

Revision 4

\subsection{REFERENCES}

1. Solid Heterogeneous Job Control Waste Raw Material Characterization, WSRC-RP-95-897, Revision 1, October 27, 1997

2. Low-Leoel Radioactioe Waste Acceptance Criteria, Manual 1S, WAC 3.17, Savannah River Site Waste Acceptance Criteria Manual.

3. E. F. Kay, HB-Line Facility Radioisotopic Sampling Plan, NMP-STE-94-0089.

4. Chart of the Nuclides, Fourteenth Edition, The General Electric Company, 1989.

5. H-Canyon Safety Analysis Report, DPSTSA-200-10, SUP-5.

6. S. J. Snyder, HB-Line Low Level Waste Validation Study (U), NMP-SNB-94-0260.

7. R. S. Thomason, Radioisotope Characterization of FB-Line Low-Level Waste (U), WSRRC-TR-94-0288.

8. J.L. Dunning, Evaluation/Validation of the 221-HBL Radionuclide Distribution, NMS-EHB-960011.

9. L.E. Rykken, Approval of HB-Line Sample Analysis Validation (U), SWE-SWC-96-0074 SWM-WCB-9410.

10. M.C. Thompson to R.S. Thomason, Estimation of Decontamination Factors for FB-Line Low Level Waste, SRT-CTS-94-0086, Rev.1, August 15, 1994.

11. D.P. Diprete to R.W. Jackson, Results- Radiological Analysis of the Mark-42 Sample (U), SRT-ADS-961186, June 11, 1996.

12. R.L. Webb, Production Limits for Fission Product Ratios (U), EPD-CTG-94-0006, June 15, 1996.

13. J. R. Chandler, Radionuclide Compositions, Chapter 13.6, Preliminary Technical Data Summary DEFENSE WASTE PROCESSING FACILITY, Stage 2,(U) DPSTD-80-39.

14. D. C. Poprik, Decontamination Factors for Impurities Possibly Contained in the H-Canyon Frames Anion Exchange Pu Product Stream (U), SRT-CTS-94-0119.

15. Information for Determination of HB-Line Low Level Waste Classification, NMP-EHA-930754. 


\section{Appendix A}

Appendix A provides the calculations for HB-Line composite distribution, the development of the smear-to-curie conversion algorithms, the associated algorithm limits, and the reportability requirements.

COMPOSITE DISTRIBUTION CALCULATIONS:

Column a list 22 isotopes that must be quantified or determined to be below the reporting threshold. -They are in order non-TRU isotopes followed by TRU isotopes.

Columns b, c, and d are the Pu-238, Pu-239, and Pu-242 distributions.

Columns $e, f$, and $g$ are the curie content for 22 of the radioisotopes, calculated using the respective algorithms, based on a 1000 pound B-25, where all waste came from rooms posted at 1,000,000 dpm alpha.

Column $\mathrm{h}$ is the composite distribution where the maximum value for each isotope from columns $e, f$, and $\mathrm{g}$ was listed. These values are summed at the bottom of the column:

Column $I$ is the normalized, composite activity distribution with the Total Activity set to unity. This distribution is used to calculate reportability.

Column 1 is the package limit for each B-25 from the $1 \mathrm{~S}$ manual.

Column $m$ is the MRQ as defined in the 15 manual as one thousandth of the package limit.

Column $n$ is the worst case activity for the limiting case B-25 (1000 lbs at the TRU limit).

By dividing the sum of the curies in the un-normalized composite (column h) by $1000 \mathrm{lbs}$ and $1,000,000$ $\mathrm{dpm}$, the constant is defined to be $4.89 \mathrm{E}-03$. The new constant for the algorithm is back calculated using the theoretical $1000 \mathrm{lb}$ B-25 with waste from rooms posted at 1,000,000 dpm. 
Appendix A

Isotope 238 Dist (Ci) 239 Dist (Ci) 242 Dist (Ci) 238 Ci Basis 239 Ci Basis 242 Ci Basis Comp Dist Norm Comp Pkg Lt (CD) MRQ Worst Case ACt

\begin{tabular}{|c|c|c|c|c|c|c|c|c|c|c|c|}
\hline$a$ & $b$ & c & $d$ & $\theta$ & $f$ & $g$ & $n$ & i & 1 & $m$ & $n$ \\
\hline$c-14$ & $6.00 \mathrm{E}-0.05$ & $7.20 E-08$ & $1.60 \mathrm{E}-06$ & $1.86 \mathrm{E}+01$ & $1.62 E-01$ & $7.36 \mathrm{E}+00$ & $1.86 \mathrm{E}+01$ & 3.80E-06 & $3.30 E-03$ & $3.30 \mathrm{E}-06$ & $1.73 E-07$ \\
\hline Co & $2.60 E-04$ & $0.00 E+00$ & $7.20 E-11$ & $8.06 E+01$ & $0.00 E+00$ & 3.3IE-04 & $8.06 E+01$ & $1.65 E-05$ & $2.30 \mathrm{E}+01$ & $2.30 E-02$ & $7.48 E-07$ \\
\hline Cs & $1.00 E-02$ & $2.05 E-06$ & $1.10 E-09$ & $3.10 \mathrm{E}+03$ & $4.61 E+\infty 0$ & $5.06 E-03$ & $3.10 E+03$ & 6.34E-04 & $7.60 \mathrm{E}-01$ & $7.60 \mathrm{E}-04$ & 2.88E-05 \\
\hline$H-3$ & $1.80 \mathrm{E}-04$ & $3.12 E-05$ & $1.30 E-09$ & $5.58 \mathrm{E}+01$ & $7.02 E+01$ & $5.98 E-03$ & $7.02 E+01$ & 1.44E-05 & $1.00 \mathrm{E}+01$ & $1.00 \mathrm{E}-02$ & $6.52 E-07$ \\
\hline 1 & $4.80 E-06$ & $5.94 E-13$ & $6.30 E-08$ & $1.49 E+00$ & $1.34 \mathrm{E}-06$ & $2.90 E-01$ & $1.49 E+\infty$ & $3.04 E-07$ & $8.30 E-08$ & $8.30 E-11$ & $1.38 E-08$ \\
\hline $\mathrm{Ni}$ & $3.70 E-07$ & $1.68 E-05$ & $3.00 E-10$ & $1.15 E-01$ & $3.78 E+01$ & $1.38 E-03$ & $3.78 \mathrm{E}+$ ㅇ? & 7.73E-06 & $6.30 \mathrm{E}-02$ & 6.30E-05 & 3.51E-07 \\
\hline Se & $7.60 \mathrm{E}-06$ & $7.20 \mathrm{E}-12$ & $9.20 \mathrm{E}-13$ & $2.36 \mathrm{E}+00$ & $1.62 \mathrm{E}-05$ & $4.23 E-06$ & $2.36 \mathrm{E} \div 00$ & 4.82E-07 & 5.20E-04 & 5.20E-07 & 2.19E-08 \\
\hline Sn & $1.10 E-08$ & $1.18 \mathrm{E}-12$ & $9.50 E-10$ & $3.41 E-03$ & 2.66E-06 & 4.37E-03 & 4.37E-03 & 8.94E-10 & $2.90 \mathrm{E}-04$ & 2.90E-07 & $4.06 E-11$ \\
\hline $\mathrm{Sr}$ & $3.60 E-03$ & $1.53 E-06$ & $1.40 E-09$ & $1.12 E+03$ & $3.44 E+\infty 0$ & $6.44 E-03$ & $1.12 E+03$ & $2.28 \mathrm{E}-04$ & $1.10 E+\infty$ & $1.10 E-03$ & $1.04 E-05$ \\
\hline TC & $3.00 E-05$ & $2.69 E-10$ & $9.40 \mathrm{E}-08$ & $9.30 E+\infty 0$ & $6.05 E-04$ & $4.32 E-01$ & $9.30 E+\infty 0$ & $1.90 \mathrm{E}-06$ & $1.70 E-04$ & 1.70E-07 & 8.63E-08 \\
\hline U-233 & $2.80 \mathrm{E}-11$ & $7.08 \mathrm{E}-14$ & $1.00 E-08$ & 8.68E-06 & 1.59E-07 & $4.60 E-02$ & 4.60E-02 & $9.41 E-09$ & 2.20E-05 & 2.20E-08 & 4.27E-10 \\
\hline U-234 & $5.10 E-05$ & 3.7IE-14 & $8.10 E-08$ & $1.58 \mathrm{E}+01$ & 8.35E-08 & 3.73E-01 & $1.58 E+01$ & $3.23 \mathrm{E}-06$ & $7.50 E-03$ & $7.50 E-06$ & $1.47 E-07$ \\
\hline U-235 & 4.10E-23 & $5.84 E-13$ & $1.40 E-11$ & $1.27 \mathrm{E}-17$ & $1.31 E-06$ & $6.44 E-05$ & $6.44 \mathrm{E}-05$ & $1.32 E-11$ & $1.10 E-04$ & $1.10 E-07$ & $5.98 \mathrm{E}-13$ \\
\hline U-236 & $2.30 E-21$ & $5.75 E-13$ & 2.40E-10 & 7.13E-16 & $1.29 \mathrm{E}-06$ & $1.10 E-03$ & $1.10 E-03$ & $2.26 \mathrm{E}-10$ & $1.40 F-03$ & $1,40 E-06$ & $1.02 E-11$ \\
\hline$U-238$ & $1.10 E-23$ & $5.35 \mathrm{E}-11$ & 7.20E-11 & $3.41 E-18$ & $1.20 E-04$ & $3.31 E-04$ & $3.31 E-04$ & $6.77 \mathrm{E}-11$. & $2.30 E-03$ & $2.30 E-06$ & $3.07 E-12$ \\
\hline Np-237 & $3.50 E-05$ & $1.64 \mathrm{E}-09$ & 9.50E-07 & $1.09 E+01$ & 3.69E-03 & $4.37 E+\infty 0$ & $1.09 E+01$ & 2.22E-06 & 2.20E-05 & 2.20E-08 & $1.01 E-07$ \\
\hline Pu-238 & $9.60 \mathrm{E}-01$ & $2.72 E-03$ & $5.00 E-02$ & $2.98 E+05$ & $6.12 E+03$ & $2.30 F+05$ & $2.98 E+05$ & 6.09E-02 & $9.10 E-02$ & $9.10 E-05$ & $2.76 E-03$ \\
\hline Pu-239 & $7.00 \mathrm{E}-04$ & $9.13 E-02$ & $6.20 E-04$ & $2.17 E+02$ & $2.05 E+06$ & $2.85 E+03$ & $2.05 \mathrm{E}+05$ & $4.20 E-02$ & $9.10 E-02$ & $9.10 E-05$ & $1.91 E-03$ \\
\hline Pu-240 & $4.90 E-04$ & $2.13 E-02$ & $1.30 E-02$ & $1.52 E+02$ & $4.79 E+04$ & $5.98 E+04$ & $5.98 E+04$ & $1.22 E-02$ & $9.10 E-02$ & $9.10 E-05$ & $5.55 E-04$ \\
\hline Pu-241 & $1.90 E-02$ & $8.67 E-01$ & $9.30 \mathrm{E}-01$ & $5.89 E+03$ & $1.95 E+06$ & $4.28 E+06$ & $4.28 E+06$ & 8.75E-01 & $1.10 E+\infty 0$ & $1.10 E-03$ & 3.97E-02 \\
\hline Pu-242 & $3.50 E-07$ & $1.97 \mathrm{E}-06$ & $1.10 E-03$ & 1.09E-01 & $4.43 E+\infty$ & $5.06 E+03$ & $5.06 E+03$ & $1.03 E-03$ & $9.10 E-02$ & $9.10 E-05$ & 4.70E-05 \\
\hline \multirow[t]{2}{*}{ Am-241 } & $1.00 \mathrm{E}-03$ & $1.78 E-02$ & $7.80 E-06$ & $3.10 E+02$ & $4.01 E+04$ & $3.59 E+01$ & $4.01 E+04$ & 8.19E-03 & $2.30 E+00$ & 2.30E-03 & $3.72 \mathrm{E}-04$ \\
\hline & $9.95 E-01$ & $1.00 E+00$ & $9.95 E-01$ & $3.09 E+05$ & $2.25 E+\infty 8$ & $4.58 E+06$ & $4.89 E+06$ & $1.00 E+00$ & & & \\
\hline
\end{tabular}

Alg Calc Rm Pst (dpm) B-25 Wt (lb) Alg Const. nCl Total

$\begin{array}{lllll}\text { Pu-238 Dist } & 1,000,000 & 1000 & 3.10 E-04 & 3.10 E+05 \\ \text { Pu-239 Dist } & 1,000,000 & 1000 & 2.25 E-03 & 2.25 E+06 \\ \text { Pu-242 Dist } & 1,000,000 & 1000 & 4.60 E-03 & 4.60 E+06 \\ \text { Comp. Dist } & 1,000,000 & 1000 & 4.89 E-03 & 4.89 E+06\end{array}$

NON-HUT WASTE 
Isotope 238 Dist (Cl) 239 Dist (Ci) 242 Dist (Cl) 238 Cl Basis 239 Cl Basis 242 Cl Basis Comp Dist Norm Comp

\begin{tabular}{|c|c|c|c|c|c|c|c|c|}
\hline a & b & c & $a$ & $\theta$ & $f$ & $g$ & h & 1 \\
\hline$C-14$ & $6.00 E-05$ & $7.20 E-08$ & $1.60 E-06$ & $1.08 E+04$ & $9.22 \mathrm{E}+01$ & $4.14 E+03$ & $1.08 E+04$ & $3.91 E-06$ \\
\hline Co & $2.60 E-04$ & $0.00 E+00$ & $7.20 \mathrm{E}-11$ & $4.68 E+04$ & $0.00 E+00$ & $1.86 \mathrm{E}-01$ & $4.68 E+04$ & $1.70 E-05$ \\
\hline Cs & $1.00 E-02$ & $2.05 E-06$ & $1.10 E-09$ & $1.80 E+06$ & $2.62 E+03$ & $2.85 E+\infty 0$ & $1.80 E+06$ & $6.52 E-04$ \\
\hline $\mathrm{H}-3$ & $1.80 E-04$ & $3.12 E-05$ & $1.30 E-09$ & $3.24 E+04$ & $3.99 E+04$ & $3.37 E+\infty 0$ & $3.99 E+04$ & $1.45 E-05$ \\
\hline 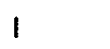 & 4.80E-06 & $5.94 E-13$ & $6.30 E-08$ & $8.64 E+02$ & $7.60 E-04$ & $1.63 E+02$ & $8.64 E+02$ & $3.13 E-07$ \\
\hline $\mathrm{Ni}$ & $3.70 E-07$ & $1.68 E-05$ & 3.00E-10 & $6.66 E+01$ & $2.15 E+04$ & $7.77 E=01$ & $2.15 E+04$ & $7.79 \mathrm{E}-06$ \\
\hline Se & $7.60 E-06$ & $7.20 E-12$ & $9.20 E-13$ & $1.37 E+03$ & $9.22 E-03$ & $2.38 E-03$ & $1.37 \mathrm{E}+03$ & $4.96 \mathrm{E}-07$ \\
\hline Sn & $1.10 E-08$ & $1.18 E-12$ & $9.50 E-10$ & $1.98 E+00$ & $1.51 E-03$ & $2.46 E+\infty 0$ & $2.46 E+00$ & $8.91 E-10$ \\
\hline$S r$ & $3.60 E-03$ & $1.53 E-06$ & $1.40 E-09$ & $6.48 E+05$ & $1.96 \mathrm{E}+03$ & $3.63 E+00$ & $6.48 E+05$ & 2.35E-OQ \\
\hline TC & $3.00 E-05$ & $2.69 E-10$ & 9.40E-08 & $5.40 E+03$ & $3.44 E-01$ & $2,43 E+02$ & $5.40 E+03$ & $1.96 \mathrm{E}-06$ \\
\hline U-233 & 2.80E-11 & 7.08E-14 & $1.00 E-08$ & $5.04 E-03$ & $9.06 E-05$ & $2.59 E+01$ & $2.59 E+01$ & $9.38 E-09$ \\
\hline U-234 & $5.10 E-05$ & $3.71 \mathrm{E}-14$ & $8.10 E-08$ & $9.18 E+03$ & 4.75E-05 & $2.10 E+02$ & $9.18 E+03$ & $3.33 \mathrm{E}-06$ \\
\hline U-235 & $4.10 E-23$ & $5.84 E-13$ & $1.40 E-11$ & $7.38 E-15$ & $7.48 E-04$ & $3.63 E-02$ & $3.63 E-02$ & $1.31 E-11$ \\
\hline U-236 & $2.30 \mathrm{E}-21$ & $5.75 E-13$ & $2.40 E-10$ & $4.14 E-13$ & 7.36E-04 & $6.22 E-01$ & $6.22 E-01$ & $2.25 \mathrm{E}-10$ \\
\hline U-238 & $1.10 E-23$ & 5.35E-11 & $7.20 E-11$ & $1.98 E-15$ & 6.86E-02 & $1.86 E-01$ & $1.86 E-01$ & $6.76 \mathrm{E}-11$ \\
\hline $\mathrm{Np}-237$ & 3.50E-05 & $1.64 E-09$ & 9.50E-07 & $6.30 E+D 3$ & 2.10E+00 & $2.46 \mathrm{E}+03$ & $6.30 \mathrm{E}+03$ & $2.28 E-06$ \\
\hline Pu-238 & $9.60 \mathrm{E}-01$ & $2.72 E-03$ & $5.00 E-02$ & $1.73 \mathrm{E}+08$ & $3.48 E+06$ & $1.30 E+08$ & $1.73 E+08$ & $6.26 E-02$ \\
\hline PU-239 & 7.00E-04 & $9.13 E-02$ & 6.20E-04 & $1.26 E+05$ & $1.17 E+08$ & $1.61 E+06$ & $1.17 E+08$ & $4.23 E-02$ \\
\hline Pu-240 & $4.90 \mathrm{E}-04$ & 2.13E-02 & $1.30 \mathrm{E}-02$ & $8.82 E+04$ & $2.73 E+07$ & $3.37 E+07$ & $3.37 \mathrm{E}+07$ & $1.22 E-02$ \\
\hline Pu-241 & $1.90 \mathrm{E}-02$ & $8.67 E-01$ & 9.30E-01 & $3.42 E+06$ & $1.11 E+09$ & $2.41 E+09$ & $2.41 \mathrm{E}+09$ & $8.73 E-01$ \\
\hline $1-242$ & $3.50 \mathrm{E}-07$ & $1.97 E-06$ & $1.10 E-03$ & $6.30 E+01$ & $2.52 E+03$ & $2.85 E+06$ & $2.85 E+06$ & $1.03 E-03$ \\
\hline \multirow[t]{2}{*}{ Am-241 } & $1.00 E-03$ & $1.78 E-02$ & $7.80 E-06$ & $1.80 \mathrm{E}+05$ & 2.2.28E+07 & $2.02 E+04$ & $2.28 E+07$ & $8.25 E-03$. \\
\hline & $9.95 \mathrm{E}-01$ & $1.00 E+00$ & $9.95 \mathrm{E}-01$ & $1.79 E+08$ & $1.28 E+09$ & $2.58 E+09$ & $2.76 E+09$ & $1.00 E+00$ \\
\hline
\end{tabular}

Alg Calc Rm Pst (dpm) B-25 Wt (b) Alg Const. . nCl Total

$\begin{array}{lllll}\text { Pu-238 Dist } & 1,000,000 & 1000 & 1.80 E-01 & 1.80 E+08 \\ \text { PU-239 Dist } & 1,000,000 & 1000 & 1.28 E+00 & 1.28 E+09 \\ \text { Pu-242 Dist } & 1,000,000 & 1000 & 2.59 E+00 & 2.59 E+09 \\ \text { Comp. Dist } & 1,000,000 & 1000 & 2.76 E+00 & 2.76 E+09\end{array}$

\section{HUT WASTE}


Appendix A

MINIMUM ROOM POSTING TO BE MANIFESTED

Alpha Aclivity on $1 \mathrm{lb} \cdot \mathrm{LLW}=12 \mathrm{nCl}$

Total Activity for composite distribution $=12 \mathrm{nCl} * 8=90 \mathrm{nCl}$

Minimum room posting

$18404.908 \mathrm{dpm} / 100 \mathrm{~cm} 2$ alpha
Composite Ratios

$$
\begin{array}{lr}
\text { TRU } & 1.24 E-01 \\
\text { Alpha } & 1.24 E-01 \\
\text { Total } & 1.00 E+00 \\
\text { Total/ Alpha } & 8.04392447 \\
\text { TRU/ Alpha } & 0.999973917
\end{array}
$$

MAXIMUM LOW LEVEL WASTE ROOM POSTING CALCULATIION

Assigned Alpha Activity of non-hut waste

$$
\text { 3.41E-04 }
$$

Assigned Waste ltem Total TRU Activity for composite distribution

Total TRU Acthity = Alpha Activity " TRU Acthily/ Alpha Activity Ratio

$$
\text { 3.41E-04 AW (nCi) }
$$

Maximum Low Level Waste Room Posting

$T(T R U)=3 E-04$ AW (nCl) > 100 nCi/g W 454g/lb

$1.33 E+08 \mathrm{dpm} / 100 \mathrm{~cm} 2$ alpha 
APPENDIX B

WSRC-TR-94-0371

Revision 4

HB-Line "Non-Hur" LLW Isotopic Quantities vs. EAV Package Limits

\begin{tabular}{|c|c|c|c|c|}
\hline isotope & $\begin{array}{c}\text { HBL } \\
\text { "Non-Hut" Dist } \\
\text { (Rel Activlty) }\end{array}$ & $\begin{array}{l}\text { UW Isotopic } \\
\text { Quantities } \\
\text { in B-25s @ } \\
\frac{1000000}{\text { (dpm/100cm2) }}\end{array}$ & $\begin{array}{l}\text { EAV Package } \\
\text { Guide - B-25s } \\
\text { (C) }\end{array}$ & $\begin{array}{l}\text { Fraction of } \\
\text { EAV Gulde }\end{array}$ \\
\hline U-238 & $6.80 \mathrm{E}-11$ & $7.98 \mathrm{E}-13$ & & \\
\hline TC-99 & $1.90 E-06$ & 5.53E-09 & $1.7 E-03$ & $3.23 E-06$ \\
\hline U-235 & $1.30 E-11$ & $3.78 E-14$ & & \\
\hline U-236 & $2.30 \mathrm{E}-10$ & $6.69 E-13$ & & \\
\hline $\mathrm{Np}-237^{*}$ & $2.20 E-06$ & $6.40 E-09$ & $2.2 \mathrm{E}-04$ & $2.96 \mathrm{E}-05$ \\
\hline $1-129$ & 3.00E-07. & $8.73 E-10$ & $8.3 E-07$ & $1.05 E-03$ \\
\hline$U-234$ & $3.20 E-06$ & $9.31 E-09$ & 2.7E-02 & $3.45 E-07$ \\
\hline $\mathrm{Pu}-239^{*}$ & 4.20E-02 & $1.22 E-04$ & $1.4 \mathrm{E}-01$ & 8.49E-04 \\
\hline Pu-241 & $8.80 E-01$ & $2.56 E-03$ & & \\
\hline $\mathrm{H}-3$ & $1.40 E-05$ & 4.07E-08 & $9.9 E+02$ & 4.1IE-11 \\
\hline Pu-240* & $1.20 E-02$ & 3.49E-05 & & \\
\hline Am-241* & $8.20 E-03$ & $2.39 E-05$ - & & \\
\hline Sn-126 & $8.90 E-10$ & $2.59 E-12$ & & · \\
\hline $\mathrm{Se}-79$ & $4.80 E-07$ & 1.40E-09 & & \\
\hline Cs-137 & $6.30 E-04$ & $1.83 E-06$ & $7.6 E+00$ & $2.42 E-07$ \\
\hline $\mathrm{Pu}-238^{*}$ & $6.10 \mathrm{E}-02$ & $1.77 E-04$ & $6.2 E-01$ & $2.86 E-04$ \\
\hline St-90 & 2.30E-04 & $6.69 E-07$ & $2.2 E+02$ & 3.10E-09 \\
\hline U-233 & 9.40E-09 & $2.73 E-11$ & & \\
\hline Ni-59 & 7.70E-06 & 2.24E-08 & $6.3 E-01$ & 3.56E-08 \\
\hline Pu-242* & 1.00 E-03 & $2.91 E-06$ & & \\
\hline$C-14$ & 3.80E-06 & $1.11 E-08$ & 3.3E-02 & $3.32 E-07$ \\
\hline Co- 60 & $1.60 \mathrm{E}-05$ & 4.66E-08 & $1.9 E+03$ & $2.46 E-11$ \\
\hline Total & $1.01 E+\infty 0$ & $2.92 E-03$ & & \\
\hline
\end{tabular}

Sum of the Fraction (SOF) $2.22 \mathrm{E}-03$

Contamination Level @ SOF (dpm/100cm2) 4.50E+08

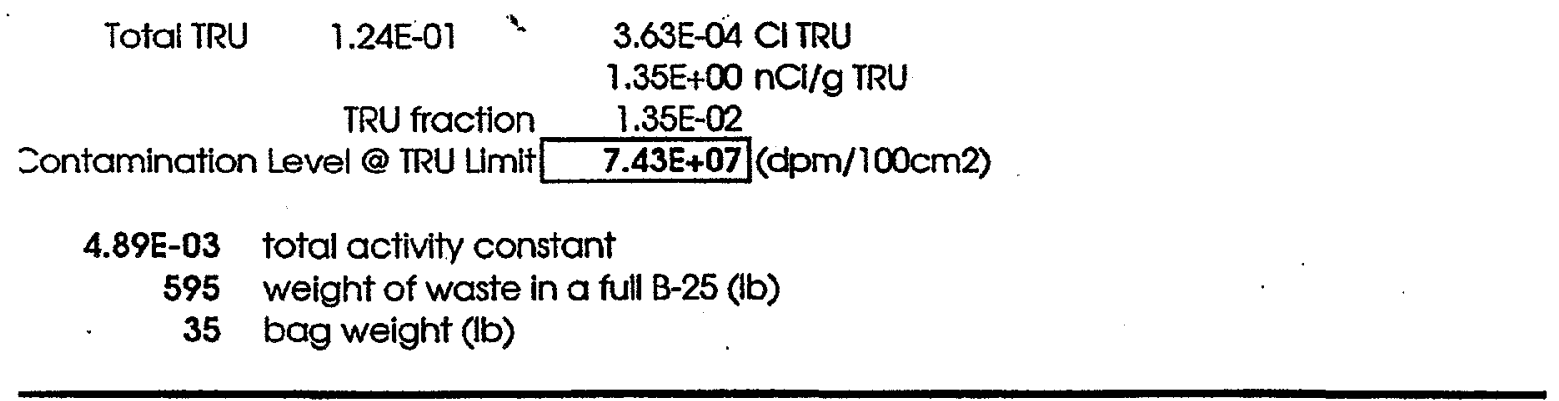




\section{EAV FISSILE GRAM EQUIVALENT CALCULATIONS}

\section{MAXIMUM FGE}

Isotope

HBL Isotopic Quantities (CD)

$\begin{array}{cc}\begin{array}{c}\text { Non-Hut" Dist } \\ \text { (Rel Activity). }\end{array} & \begin{array}{c}\text { in B-25 @ } \\ \text { dpm/100 } / 10 \mathrm{~cm} 2\end{array}\end{array}$

$\begin{array}{lll}\text { Pu-239* } & 4.2 E-02 & 9.08 E-03 \\ \text { Pu-241 } & 8.8 E-01 & 1.90 E-01 \\ \text { U-235 } & 1.3 E-11 & 2.81 E-12 \\ \text { U-233 } & 9.4 E-09 & 2.03 E-09\end{array}$

Actlvity (C) @ Specific Activity

\begin{tabular}{|c|c|c|c|c|c|c|}
\hline Isotope & $\begin{array}{l}\text { above contam IVI } \\
\text { (A) }\end{array}$ & $\begin{array}{c}(\mathrm{Cl} / \mathrm{g}) \\
(\mathrm{B})\end{array}$ & & $\begin{array}{c}\text { Mass Amou } \\
(C=A / B)\end{array}$ & $\begin{array}{l}\text { Conversior } \\
\text { Factor (D) }\end{array}$ & $\begin{array}{l}G E U-2 \\
(C \times D)\end{array}$ \\
\hline Pu-239* & $9.08 \mathrm{E}-03$ & $6.13 E-02$ & - & $1.48 \mathrm{E}-01$ & $\frac{1.6}{1.6}$ & $2.37 \mathrm{E}-01$ \\
\hline Pu-241 & $1.90 E-01$ & $1.03 E+02$ & & $1.85 E-03$ & 3.5 & $6.46 E-03$ \\
\hline U-235 & $2.81 E-12$ & $2.16 E-06$ & & $1.30 E-06$ & 1 & $1.30 E-06$ \\
\hline U-233 & 2.03E-09 & $9.65 E-03$ & & $2.11 \mathrm{E}-07$ & $\begin{array}{c}1.4 \\
\text { TOTAL }\end{array}$ & $\frac{2.95 \mathrm{E}-07}{2.43 \mathrm{E}-01}$ \\
\hline
\end{tabular}

2. Determine the contamination level at which the FGE limit is reached and verify that the FGE contamination level is not the bounding case.

$\begin{array}{cccc} & & \begin{array}{c}\text { Contam Rate @ } \\ \text { the FGE Umit }\end{array} \\ \text { FGE (g) } & \text { FGE Umit (g) } & \begin{array}{c}\text { FGE } \\ \text { Fraction }(\mathrm{dpm} / 100 \mathrm{~cm} 2)\end{array} \\ 2.43 \mathrm{E}-01 & 50 & 0.00486941 .53 \mathrm{E}+10 .\end{array}$

3. Since $7.43 E 7 \mathrm{dpm} / 100 \mathrm{~cm} 2$ is less than $1.53 E 10 \mathrm{dpm} / 100 \mathrm{~cm} 2$, the TRU limit of $7.43 E 7$ $\mathrm{dpm} / 100 \mathrm{~cm} 2$ is the boundling case.

Therefore 0.24 grams is a maximum that would be shipped from the HB-Line non-hut waste strer The actual value to be calculated by WITS. 


\begin{tabular}{|c|c|c|}
\hline \multicolumn{3}{|c|}{$\begin{array}{l}\text { HB-Line "Non-Huf" LLW Isotopic Quantities vs. CIF Package } \\
\text { CONTAMINATION LEVEL AT THE ALPHA LIMIT }\end{array}$} \\
\hline \multicolumn{3}{|c|}{$\begin{array}{lcc}\text { Isotope } & \text { HBL } & \text { LW Isotopic Quantities (CD) } \\
\text { "Non-Hut" Dist } & 1-35 \text { Pound Bag @ } \\
\text { (Rel Activity) } & \frac{\mid 1000000}{\mathrm{dpm} / 100 \mathrm{~cm} 2}\end{array}$} \\
\hline 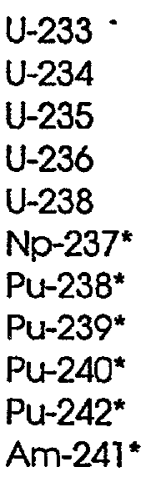 & $\begin{array}{l}9.40 \mathrm{E}-09 \\
3.20 \mathrm{E}-06 \\
1.30 \mathrm{E}-11 \\
2.30 \mathrm{E}-10 \\
6.80 \mathrm{E}-11 \\
2.20 \mathrm{E}-06 \\
6.10 \mathrm{E}-02 \\
4.20 \mathrm{E}-02 \\
1.20 \mathrm{E}-02 \\
1.00 \mathrm{E}-03 \\
8.20 \mathrm{E}-03\end{array}$ & $\begin{array}{l}1.61 E-12 \\
5.48 E-10 \\
2.22 E-15 \\
3.94 E-14 \\
1.16 E-14 \\
3.77 E-10 \\
1.04 E-05 \\
7.19 E-06 \\
2.05 E-06 \\
1.71 E-07 \\
1.40 E-06\end{array}$ \\
\hline Am-241* & & \\
\hline
\end{tabular}

Fraction of Contam Rate @

Alpha Content (nCi/g) Alpha Threshold Alpha alphathreshold $(\mathrm{nCl} / \mathrm{g})$ Threshold (dpm/100 cm2)

$1.34 \mathrm{E}+00 \quad 100.0 \quad 1.34 \mathrm{E}-02 \quad 7.47 \mathrm{E}+07$

Note: List of alpha emitters provided by R. S. Thomason of NMS\&S Engineering Support CONTAMINATION LEVEL AT THE TRITIUM LIMIT
Isotope
HBL LLW Isotopic Qty (C)
"Non-Hut" Dist 1-35Pound Bag @
(Rel Activity) $\frac{1000000}{\mathrm{dpm} / 100 \mathrm{~cm} 2}$
$\mathrm{H}-3$
$1.40 \mathrm{E}-05 \quad 2.40 \mathrm{E}-09$
$\mathrm{H}-3$ Conc. (nCi/g) $\quad \mathrm{H}-3$ Limit $\quad$ Fraction of Contam @ H-3
(nCl/g) ClF Limit Limit (dpm/100 cm2)
1.51E-04 $100000 \quad 1.509 \mathrm{E}-096.63 \mathrm{E}+14$




\section{CONTAMINATION LEVEL AT THE TOTAL CONCENTRATION UIMIT}

Isotope HBL UW isotopic QTy (CD)

"Non-Hut" Dist 1:35Pound Bag @

(Rel Activity)

U-238

TC-99

U-235

$\mathrm{U}-236$.

$\mathrm{Np}-237^{*}$

$1-129$

U-234

Pu-239*

Pu-241

$\mathrm{H}-3$

$\mathrm{Pu}-240^{*}$

Am-241 *

Sn-126

Se-79

Cs-137

$\mathrm{Pu}-238^{*}$

ST-90

U-233

Ni-59

Pu-242*

C-14

Co-60

6.80E-11

1.90E-06

1.30E-11

2.30E-10

2.20E-06

3.00E-07

3.20E-06

4.20E-02

8.80E-0.1

1.40E-05

$\frac{1000000}{\mathrm{dpm} / 100 \mathrm{~cm} 2}$

$1.20 \mathrm{E}-02$

1.16E-14

3.25E-10

2.22E-15

3.94E-14

3.77E-10

5.13E-11

5.48E-10

7.19E-06

1.51E-04

2.40E-09

2.05E-06

8.20E-03

8.90E-10

2.05E-06

$1.40 E-06$

4.80E-07

1.52E-13

6.30E-04

8.22E-11

6.10E-02

1.08E-07

2.30E-04

1.04E-05

9.40E-09

3.94E-08

7.70E-06

1.61E-12

$1.00 \mathrm{E}-03$

$1.32 \mathrm{E}-09$

3.80E-06

$1.71 E-07$

1.60E-05

6.50E-10

Total $\mathrm{Cl}=$

1.74E-04

Total Concentration (nCl/g)

10.965

\begin{tabular}{cc} 
Total Conc & \multicolumn{2}{c}{$\begin{array}{c}\text { Contam } \text { Total Conc } \\
\text { Limit }\end{array}$} \\
$\begin{array}{c}\text { Total Conc Lmit } \\
(\mathrm{nCl} / \mathrm{g})\end{array}$ & Fraction (dpm/100cm2) \\
230000 & $4.77 \mathrm{E}-05 \mathrm{2.10 \textrm {E } + 1 0}$
\end{tabular}

Page 4 


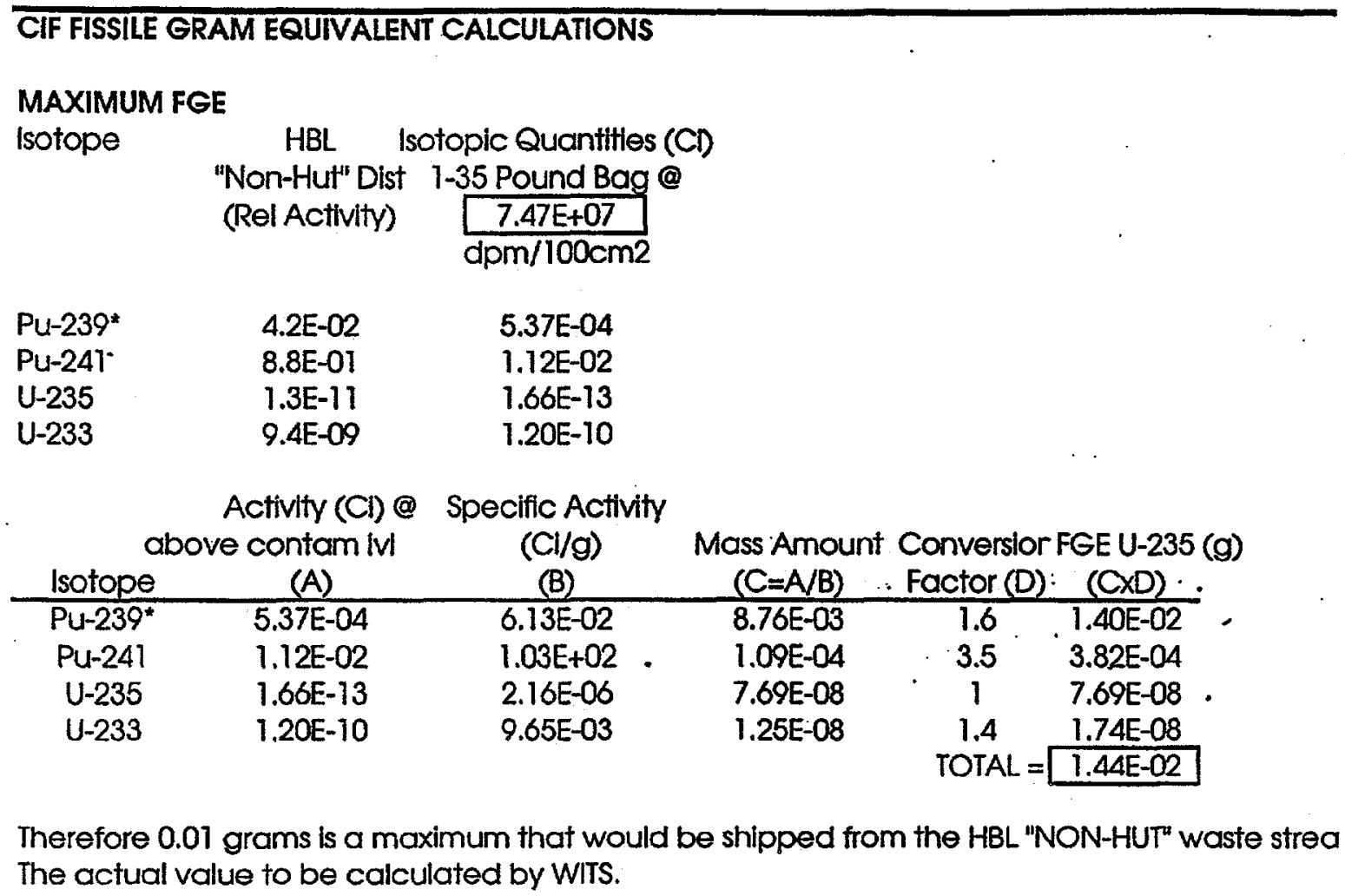

\section{AVERAGE FGE}

Isotope

HBL Isotopic Quantities (CI)

"Non-Hut" Dist 1-35 Pound Bag @

(Rel Activity) $\frac{1000000}{\mathrm{dpm} / 100 \mathrm{~cm} 2}$

$\begin{array}{lll}\text { PU-239* } & 4.2 E-02 & 7.19 E-06 \\ \text { PU-241 } & 8.8 E-01 & 1.51 E-04 \\ \text { U-235 } & 1.3 E-11 & 2.22 E-15 \\ \text { U-233 } & 9.4 E-09 & 1.61 E-12\end{array}$

Activity (Ci) @ Specific Activity above contam IVI (Cl/g) Mass Amount Conversior FGE U-235 (g)

\begin{tabular}{|c|c|c|c|c|c|}
\hline Isotope & (A) & (B) & $(C=A / B)$ & Factor (D) & $(\mathrm{C} \times \mathrm{D})$ \\
\hline Pu-239* & $7.19 \mathrm{E}-06$ & $6.13 E-02$ & $1.17 E-04$ & 1.6 & $1.88 \mathrm{E}-04$ \\
\hline Pu-241 & $1.51 \mathrm{E}-04$ & $1.03 E+02$ & $1,46 \mathrm{E}-06$ & 3.5 & $5.12 E-06$ \\
\hline U-235 & $2.22 \mathrm{E}-15$ & $2.16 E-06$ & $1.03 E-09$ & 1 & $1.03 \mathrm{E}-09$ \\
\hline U-233 & $1.61 E-12$ & $9.65 E-03$ & $1.67 E-10$ & $\begin{array}{c}1.4 \\
\text { TOTAL }\end{array}$ & $\frac{2.33 \mathrm{E}-10}{1.93 \mathrm{E}-04}$ \\
\hline
\end{tabular}

An average FGE would be 1.93E-4 grams. The actual value to be calculated by WITS. 
HB-Line "Hut" LLW Isotopic Quantitles vs. EAV Package limits

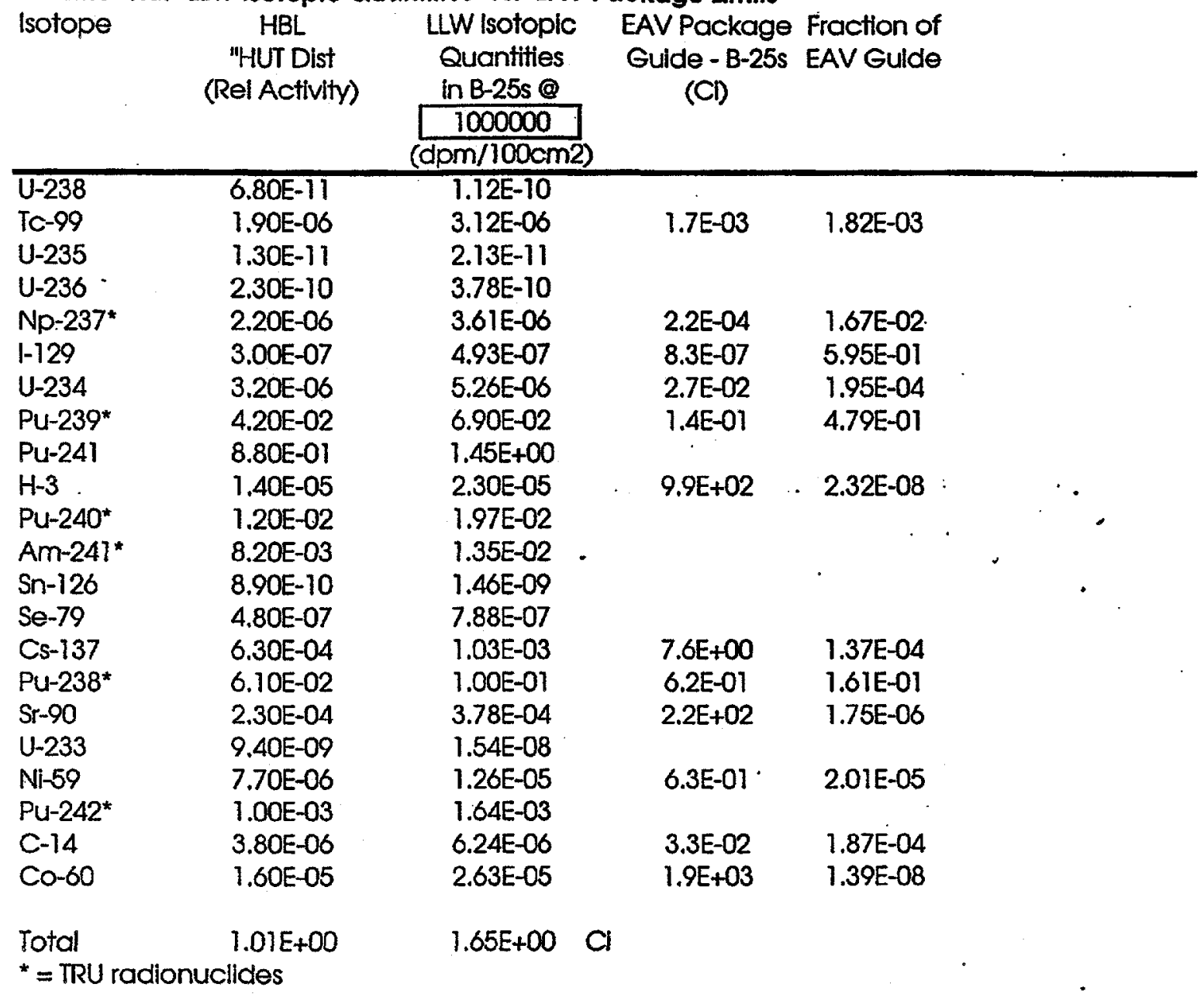

Sum of the Fraction (SOF) $\quad 1.25 E+00$

Contamination Level @ SOF (dpm/100cm2) 7.97E+05

Total TRU 1.242E-01 : 2.05E-01 CITRU

TRU fraction $7.60 \mathrm{E}+00$

Zontamination Level @ TRU Limit $1.32 \mathrm{E}+05(\mathrm{dpm} / 100 \mathrm{~cm} 2)$

2.76E+00 total activity constant

595 weight of waste in a full B-25 (lb)

35 bag weight (lb) 


\section{CHARACTERIZATION OF HB-LINE LOW-LEVEL WASTE (U) WSRC-TR-94-0371 \\ REVISION 4 ADDENDUM 1}

August, 1998

Author:

Reviewer:

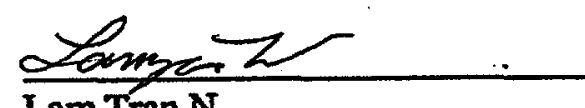

Lam Tran N.

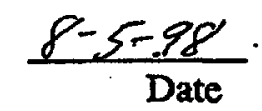

HB-Line Systems Engineering

Nuclear Materials Stabilization \& Storage

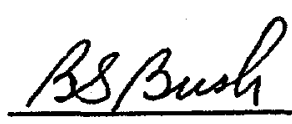

B. S. Bush, 221-HBBL HB-Line Certification Official

Nuclear Materials Stabilization \& Storage

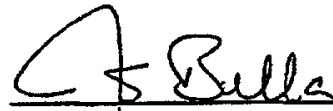

Steve Bellamy, 703-

Division Waste Contact

Nuclear Materials Stabilization \& Storage

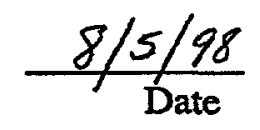

Approver:

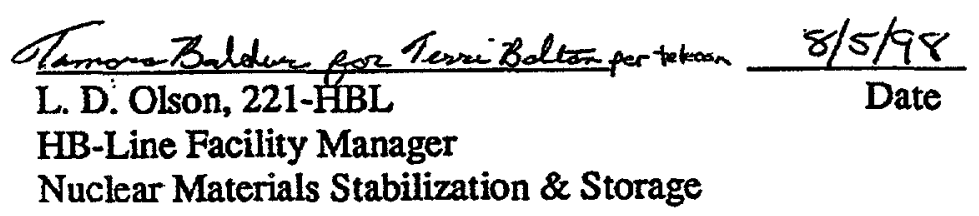


These are changes that need to be correct for the CHARACTERIZATION OF HB-LINE LOW-LEVEL WASTE:

***Note: Boldface fonts are the changes.

The section 3.1.4 in the first paragraph of page 6 should be stated as:

HB-Line does not process or use explosives, pyrophoric materials, etiologic agents, chelating agents, dioxins, or furans nor does HB-Line generate greater than 10CFR61 Class $C$ waste.

The section 3.2.10 in the first paragraph of page 9 should be stated as:

HB-Line does not process or use explosives, pyrophoric materials, etiologic agents, chelating agents, dioxins, or furans nor does HB-Line generate greater than 10CFR61 Class C waste.

The section 4.4.2 in the second paragraph of page 9 should be stated as:

H-3

NON-HUT

HUT

$$
6.63 \times 10^{14}
$$

$1.17 \times 10^{12}$
Alpha

$7.47 \times 10^{7}$

$1.32 \times 10^{5}$
Total Nuclides

$2.10 \times 10^{10}$

$3.72 \times 10^{7}$ 